\title{
RECTIFICATION AND REVIVAL OF MUSLIM WORLD
}

\author{
M. AzRaM \\ Department of Science, Faculty of Engineering, \\ International Islamic University Malaysia, \\ PO Box 10, Kuala Lumpur 50728, Malaysia.
}

azram50@hotmail.com

\begin{abstract}
The present doldrums position and state of decadence, internal differences, external aggression (geographical and ideological), lack of self-confidence and dependence, illiteracy, political instability, economic disaster, lack of knowledge and wisdom, back benchers in science and technology, education, medicine, trade and business, banking system and defensive incapability of Muslim Ummah prompted me to write this article. Although most of the Muslim nations got their independence because of their dedicated struggle and historic events and incidents but the old masters remained active for a remote control over the Muslim Ummah. Their intellectuals and scholars, individually as well as collectively, have propagated and advised their leadership, the tactics and approaches by which Muslim Ummah can again be enslaved. Writings of S.P. Huntington and F. Fukuyama are clear examples. They are actively gearing the international institutions so cleverly that Muslim Ummah does not even realize their ill motives and objectives. They brought their leadership in a confronting position with Muslim Ummah and hence threatening the world peace. This situation prompted us to look at our principal sources of inspiration, which are, the Qur'an, Sunnah of the Prophet (SAW), and examples of the "enlightened Caliphs" and see if we could work out a seminal guidelines for our rectification and revival. We have gathered together some of these impressions; these are all tentative, nothing final about them, but these are here nonetheless.
\end{abstract}

ABSTRAK: Kehadiran situasi kebelungguan dan keruntuhan, perbezaan dalaman, pencerobohan luar (geografi dan ideologi), kurang keyakinan diri dan pergantungan, buta huruf, ketidakstabilan politik, bencana ekonomi, kekurangan ilmu dan hikmah, ketinggalan dalam sains dan teknologi, pendidikan, perubatan, perdagangan dan perniagaan, sistem perbankan dan ketidakupayaan pertahanan umat Islam mendorong saya untuk menulis artikel ini. Walaupun kebanyakan negara-negara Islam mendapat kemerdekaan mereka kerana perjuangan mereka yang berdedikasi dan peristiwa dan kejadian yang bersejarah tetapi sejarah orang lama yang kekal aktif untuk mengawal kedudukan umat Islam. Keintelektuallan mereka, secara individu dan secara berkumpulan, telah dikembangkan melalui nasihat kepimpinan mereka, taktik dan pendekatan yang Muslim Ummah sekali lagi boleh diperhambakan. Karya SP Huntington dan F. Fukuyama adalah contoh yang jelas. Mereka secara aktif menggerakkan institusi antarabangsa sehingga umat Islam tidak menyedari motif tersirat dan objektif mereka. Mereka telah membawa kepimpinan mereka dalam kedudukan yang dihadapi dengan umat Islam dan dengan itu mengancam keamanan dunia. Keadaan ini mendorong kita untuk melihat sumber-sumber inspirasi utama, iaitu al-Quran, Sunnah Nabi (SAW), dan contoh-contoh "Khalifah pencerahan" dan lihat jika kita boleh merumuskan satu garis panduan pembetulan dan pemulihan. Kami telah berkumpul bersama untuk mengawal perasaan, ini semua tentatif, walau bagaimanapun tiada apaapa jua yang muktamad tentang mereka. 
IIUM Engineering Journal, Vol. 12, No. 5, 2011: Special Issue on Science and Ethics in Engineering

Azram

KEYWORDS: SWT (subhana wa taala); pbuh (peace and blessings be upon him); ra (radiallahu anha/u)

\section{INTRODUCTION}

Inner goodness and inner evil are always in conflict in all human beings. The same is also going on in a society. Whichever element (goodness or evil) excels and dominates, one is attracted to the same in the society. Consequently, one becomes either a party to Allah (حزب اله) or a party to Satan (حزب الثنيطان). The first group, i.e. messengers of Allah, faithful, righteous, martyrs, saints, mystics, devoted people, calls human beings to the guidance of Allah according to His Command and Will. They guide for selfpurification and taqwa, i.e. mysticism. Regarding the same, Imam Ghazali has said that the inner intellect of Islam is mysticism while the outer husk is jihad (for the cause of Allah). In fact this group calls human beings to be the obedient servants of Allah, Who is the real Creator and Master. They call to establish equity and justice in society; to learn, to act and perform according to His Command, Will and Guidance; to respect the rights of other human beings. They advise people to choose the path of goodness rather than evil; perform prayers; fast in the holy month of Ramadan; pay Zakat; love deeply the Prophet (pbuh). They advise to take care of and protect human dignity, respect and honor; and participate in jihad (for the cause of Allah). In fact they advise human beings to realize, to act and perform duties as real vicegerents of Allah. They advise and teach the consequences of negligence, ignorance and laziness; motivate the people to realize the need of dedication and hard work. Regarding this, one can read the Qur'an (Surah Tawbah) and recall the Tabuk expedition, wherein three highly placed dignified Muslims failed to participate, remained clinging to their homes, and were slackers just because of laziness. They had participated in the battle of Badr and Uhud, but even then Allah and His Prophet (pbuh) disliked their act. Muslim society was asked for a social boycott. In short, good deeds of their whole lives were at risk due to ignorance; not only that, their faith and belief was doubted and suspected. Finally, after their begging for mercy and showing repentance for two months, Allah revealed their forgiveness and they were accepted back in Islamic society. From this, it is fair to conclude that if someone is negligent of a social or public responsibility or duty without any sharaie (lawful) excuse, his faith and belief will be suspected, doubted and deserve a social boycott by the Islamic society. In contrast, unfortunately, the present situation of the Muslim Ummah is just the reverse. One can hardly find this kind of moral decline or degradation in any other society but still we complain that the Muslim Ummah is not given a place in the world order. The reality is that moral decadence is the root cause for this. One can recall the saying of the Prophet (pbuh) that regarding mutual love, humanity and generosity, the Muslim Ummah is just like a single organism. If any part of it suffers, the whole body feels it (Sahih AlBukhari). Noble Qur'an declares: Surely this community of yours is one community (Ummah), and I am your Lord, therefore serve Me. (Q:21:92). You may think and judge the present standing and role of the Muslim Ummah.

For understanding Islam, scholars have divided the Islamic rights, duties, and responsibilities into two categories, i.e., pure worship only for Allah (حقوق اله) and the rights of human beings (حقوق العباد). The pivotal place for the first one goes to prayer ( (الصنّلاة while for the second one it is Zakat. Prayer leads and brings us close to Allah, while Zakat keeps us linked with human beings. It is simply not possible to perform one and ignore the other, and still claim to be a Muslim. Regarding this, recall the sayings and actions of Abu Bakr Siddique (ra). He declared Jihad against those who refused to pay Zakat and said that those who used to pay Zakat during the time of Prophet (SAW) of 
even a wooden nail fixed to camel's nose, are liable to pay Zakat, otherwise jihad will continue against them [6]. As long as the Muslim Ummah was strictly observing these two principles of Islam, they were a power and their superiority, strength, solidarity and sovereignty were unquestionable. As soon as they turned their faces and started avoiding rather than sharing troubles of oppressed and deprived brethren, they were rolled back to the present insulting and disgraceful situation.

On the other hand, if inner evil dominates, mankind joins the party of Satan

and consequently, degrade to an even worse state than brutes, resulting in a real loss, resolve on mischief, worship lust rather than Allah, which is self destruction. They misguidedly assume their performance as extraordinary while the fact is that their deed's foundation is nothing but a spider's web. To Allah, their deeds are of no value. It is stated in Hadith Qudsi that "continuous performance of good deeds results in enlightenment while consistent evil-doing results in maliciousness" and consequently, the evil-doers join the party of Satan (حزب الثبطان) and lose the capability of performing good deeds. It is just like putting the goblet face down and expecting that rain will collect in it. As long as mankind and human society exist, good and evil, truth and falsehood will be at war. Habeel and Qabeel are not only two names but are also the names of two ideologies ( and the fight between them is a perpetual fact. Fortunate are those who join the party of Allah (حزب الهُ).

Presently, the Muslim Ummah is in a very disappointing situation. Muslim Ummah is in a state of decadence, internal differences, instability, external aggression both geographical and ideological, scattered, lack of self- confidence and dependence, illiteracy, disaster at political and economic fronts, lack of knowledge and wisdom, back bencher in science and technology. On the other hand, non-Muslims especially the capitalists are seriously busy and trying to establish and promote a new world order, a new form of capitalism. Communism and capitalism were threats to each other but the fact is that communism was a byproduct of capitalism and was assumed to be a better system. In fact, both are unnatural; capitalism deprives the laborers while communism deprives people of belongings and wealth. Failure is and will be the fate of both. The end of a better system cannot be a testimony to the merit and success of a bad system, which is wrongly assumed by capitalist countries. The dilemma is that the Muslim Ummah has failed to promote and establish a better alternative Islamic system; therefore, capitalism is enjoying its monopoly. Since Capitalists are trying to establish and promote capitalism, they consider Islam as a threat comparable to communism. Consequently, cruelty and aggression on all fronts against Muslims is a preplanned game. Events in Chechnya, Bosnia, Iraq, Lebanon, Somalia, Algeria, Kashmir, Palestine, Burma, Philippines and Afghanistan are clear examples. None of the Muslim countries is self-sufficient in its defensive needs and unfortunately; they do not even realize this weakness. No wonder they are being mercilessly crushed all over the world. Muslims Ummah constitute fifty seven Muslim nations with one-fifth of the world population, possess half of the world's natural resources but have virtually failed to utilize these advantages.

Being on back benches in education, medicine, science and technology, trade and industries, no single country out of the fifty seven Islamic countries or Muslim Ummah as a whole, can protect and defend their natural resources, or its geographical and ideological frontiers. The proposed world order is the last attempt to save and protect capitalism.

Capitalists are fearful that awakening of Muslims may result in losing the natural resources of the Muslim Ummah especially the Middle East. It is a fact that, wherever and whenever the leadership of Islamic movements tried to upgrade the life standard of 
the people, provided health and educational facilities, provided freedom of religious and apprehension, provided freedom of speech and writing, Allah fearing governing activities, prepared to reoccupy their own resources from the aggressor, they were considered as a threat to their interest and are declared as terrorist, extremists, fundamentalists, uncivilized, fanatic, archaic, anachronistic, destructive and lawless to justify their elimination. Unfortunately, in most of the Islamic countries, their own leaders and rulers being planted by them perform this job.

We have already said that as long as mankind remains, human history will be alive. The battle between good and evil, truth and falsehood is eternal. It will end only when there will be an end to humankind, otherwise this battle and clash will continue in some other forms. This is a most critical time for intellectuals, scholars, and leaders of Muslim Ummah. It is their moral obligation, duty and responsibility, to propagate the real spirit of Islam to Anti-Islamists so that the wrongly propagated ideas can be defused.

The solution of the world's destruction especially that of the Muslim world is concealed in the universal system of Islam, which, we failed to promote and establish because we never adopted it at home. However, the following are some of the remedial basic principles, which we have gathered together from the Qur'an, Hadith, and writings of some Muslim intellectuals.

\section{EQUALITY AND HUMAN RIGHTS}

The Qur'an has essentially addressed mankind and is a revealed treatise on humanity respect and honor. Human equality, brotherhood, freedom, reverence and greatness are in the charter of the Qur'an, wherein, after the Unity of Allah (SWT), the whole stress is on unity among mankind. After a profound study of the Qur'an, it becomes evident that there is no single verse in the Qur'an, which teaches us the art of slavery. The whole Qur'an teaches the art of salvation. The Qur'an guides and advises us to be a party of Allah حزب) (ال山 and His Prophet (pbuh). It stresses that socio-economic justice is the basic ingredient to establish peace and harmony. The Qur'an declares that humankind are the children of the same male (Adam (ra)) and a female (Eve (ra) (Q: 49: 13)); hence, they are equal and are vicegerents of Allah (SWT), with the same basic rights. Human life, property, selfrespect, and freedom ought to be respected. Regarding human life, it is stated that killing (saving) of a single life is worth killing (saving) of the whole humanity. All human beings are equal before Allah (SWT). The bases of virtue and honor are only the dignified deeds and noble character, that is, righteousness and piety. Blood, color, race, language, region or nationality may be a source of identification but not the source of distinction and glory. Regarding the same, the Qur'an says, "O Mankind! Lo! We have created you male and female, and have made you nations and tribes that ye may know one another. Lo! The noblest of you, in the sight of Allah, is the best in conduct. Lo! Allah is knower, aware" (Q: 49: 13). Similarly, "O mankind! Be careful of your duty to your Lord Who created you from a single soul and from it created its mate and from them twain hath spread abroad a multitude of men and women. Be careful of your duty toward Allah in Whom ye claim (yours rights) of one another, and toward the wombs (that bare you). Lo! Allah hath been a Watcher over you" (Q: 4: 1). Allah-fearing, devotion, politeness and good deeds are the bases of dignity, respect and honor. In fact, all standards other than noble deeds are the causes of jealousy, enmity, rivalry, quarrel and disturbances. As an example; if personnel belongings are criterion, people will use fair and unfair means to collect them, which will eventually cause mischief, trouble and disturbance. If military skill is a criterion, bloodshed will be the fate, which is obvious in the present scenario. It is the 
same with other criteria. Rivalry and jealousy will never disturb if we have Allah-fearing attitude, humility and devoutness. Consequently, human life will be the cradle of peace and mankind can enjoy it. Consider the address of the Prophet (pbuh) at the Farewell Hajj, wherein in the light of Qur'anic verse (Q: 49: 13) he has said: "All mankind are from Adam and Eve, an Arab has no superiority over a non-Arab nor has a non-Arab any superiority over an Arab; also a white has no superiority over a black nor has a black any superiority over a white - except by piety and good deeds" [2]. This implies that color, race, language, and region carry no significance. Good moral deeds will be the basis of prosperity. This was the last legacy of the last Prophet (pbuh). This historic address is an abstract of the Qur'an and a charter for equality. Mankinds are fighting against each other. It seems that there is no end to racial and linguistic disturbances. The root cause of all grouping, fights, killings, and bloodshed is prejudice, which has been discarded in the above address. Similarly, at the time of Mecca victory [3], Prophet (pbuh) said: "Oh Quraish! Allah has eliminated the barbarous pride and genealogical glory. All men are from Adam (ra) and Adam (ra) was created from the dust". Afterwards he recited the same verse of Surah Al-Hajurat (Q: 49: 13). This indicates that, this verse of Surah AlHajurat is the basic principle of equality and the Prophet's address at the farewell Hajj is the charter of humanity. Unfortunately, Muslims failed to consider it the basis in their own community.

\section{FREEDOM OF RELIGION AND THOUGHT}

The Qur'an says, there is no compulsion in Din (way of life)(La ikra'a fi din). Mao Tse Tung said that the communist revolution starts with the mouth of the gun, that is, compulsion is the only way of its establishment. Today, it is very much clear that Lenin and Stalin had established communism at the cost of human bones and skeletons, that is, millions of people were killed. The establishment of capitalism is no more different. It started with the French Revolution, wherein the basis was the bloodshed of millions of people. According to the Qur'an, Islamic revolution starts deeply from the heart wherein individuals are enlightened. Compulsion or oppression may be a source of physical rule but cannot be the source of ruling the hearts and minds of people. Force can conquer but cannot convert. Morality and good deeds can only be expected with ambitious changes and this cannot be established by force. Islamic approach is to appeal to the hearts of men, to awaken their sleeping nature, to stir their repressed inclination and desire towards progress and perfection, to return them to the presence of Allah (swt), and to adopt such a method that would have convincing arguments and the sweetness of love and brotherhood. The moral values should be explained and clarified in a manner that the heart may be convinced that it is necessary to adopt these for attaining the good and righteous qualities. The Qur'an says, "There is no compulsion in religion. The right direction is henceforth distinct from error. And he who rejecteth false deities and believeth in Allah hath grasped a firm handhold which will never break. Allah is hearer, knower" (Q: 2: 256). Similarly, "And if thy Lord willed, all who were in the earth would have believed together. Wouldst thou (Muhammad) compel men until they are believers" (Q: 10: 100). Again, "Say: O mankind! Now hath the Truth from your Lord come unto you. So whosoever erreth only against it. And I am not a warder over you" (Q: 10: 109). These verses of the Qur'an clearly explain the concern of the Prophet (pbuh) about human guidance. He said, "I have been sent only for the purpose of perfecting good morals' (Al-Muta). It was almost impossible for him to see human killing and depravity. Despite his inner grief, distraction and restlessness, he was not empowered to force any individual to enter Islam. It is the will and wishes of humankind to believe in or to reject the guidance of Allah. Just as 
equality is a matter of human honor, freedom in choosing religion, without any compulsion is a part of human respect and honor. Islam expects that wisdom and intellect should be the source for the choice of religion. In contrast to the wrong interpretation by the non-believers, Islam expanded by good conduct and moral rectitude. Indonesia, Malaysia and Africa etc are clear examples. Regarding self-respect and glory, it is advisable to be away from evil and seek blessing of Allah. Equality and freedom of belief and intellect are, as a result, the basic principles of the universal system of Islam. Disturbance in the society can be eliminated if humankind respects these principles.

\section{ESTABLISHMENT OF JUSTICE}

Establishment of justice has thoroughly been addressed in the Qur'an. A majority of intellectuals say that the root cause of the downfall or rise of the nations is justice. Many nations were empowered as a test to their ability for the establishment of justice. Nations will not be judged on the Day of Judgment but nations are to be judged here and now, in and through history (Q: 2: 213-214). If they establish a just socio-moral order in this world, Allah (swt) will be with them and they have really grasped the trust worthiest handhold. If they establish cruelty and despotism rather than a just socio-moral order, Allah (swt) lets them be ruined and replaced by some other nation. In fact, when they fail to live up to the expectations of the Qur'an, they are pushed out of the commanding position and are buried in the dust of history, probably never to be heard of again. National morality and establishment of justice are the bases for survival of nations. Islam says that the progress and survival of the nations, the nourishment and the development of their civilization and culture, and the consolidation of their power depend on morality. Nations live till their morality lives. When their moral character decline they also decline.

A famous saying of Imam Ibn Taymiyah says, "Allah guards the justice-loving government, even if it is the government of the infidels, and destroys the tyrannical government, even if it is the government of Muslims"[5]. The establishment of justice is the basis in historic ups and downs. As mentioned in many places in the Qur'an, the Muslim Ummah has been raised for the purpose of establishment of justice. Qur'an says, "O ye who believe! Be steadfast witnesses for Allah in equity, and let not hatred of any people seduce you that ye deal not justly. Deal justly, that is nearer to your duty. Observe your duty to Allah. Lo! Allah is informed of what ye do" (Q: 5: 8). Similarly, "O ye who believe! Be ye staunch in justice, witnesses for Allah, even though it be against yourselves or (your) parents or (your) kindred, whether (the case be of) a rich man or a poor man, for Allah is nearer unto both (then ye are). So follow not passion lest ye lapse (from truth) and if ye lapse or fall away, then lo! Allah is ever informed of what ye do" (Q: 4: 135). Regarding justice, the Qur' an stresses to the Muslims to practice extraordinary caution and directs them not to distort, or debase justice because of wealth, power, or poverty. The basic principles of international relations must be straightforward. Guarantor(s) must be of high moral character especially, Allah-fearing attitude, attitude of accountability to Allah (SWT), and justice loving. The present situation is very much disappointing. As an example, consider the role of UNO, wherein five nations are responsible to establish justice and peace at any cost. In practice, they only protect the interests (justified or unjustified) of their allies or those that are under their influence. Only America and Russia have used the "Veto Power" for almost a hundred times in favor of Israel or other similar countries. The expectation of a just socio-moral order from such a UNO is questionable. Character is normally judged by the doings rather than sayings. Performance and deeds are the actual reflection of professions. It will be more appropriate to determine the performances of the responsible people in the international security rather 
than their sayings. It is interesting to note that $90 \%$ of the present ammunition is owned and manufactured by the nations responsible for international security and peace. Peace is really not their concern because it will cause them a loss. It is just like leaving the wolf to watch the sheeps. According to the Qur'an, there are three types of agonies. The first type includes the havoc of wind and rain as well as cruel and despotic rulers. The second type includes earth-quakes, famines or other catastrophes as well as cruelty to the poor. In the third type, men oppress men. Presently, humanity is suffering from all three types of agonies. There must be repentance otherwise destruction will be the fate. Time is really running short for rectification. The Qur'an repeatedly reminds us to establish justice, because it brings us closer to taqwa (Allah-fearing) and Allah likes it. According to the Qur'an, justice is the spirit of all deeds; those who excel in it are successful. The book (Qur'an) that guides humanity for morality and justice should have been the source of peace and security. Unfortunately, Muslims themselves do not follow it, how can they invite others?

\section{FULFILMENT OF PROMISES}

Islam discourages the tendency of breaking both individual and social promises and crossing the limits. False promises are termed as symbol of disruption and cause of untold harm to society. Relying on falsehood is unwise and brings a bad name. Words become worthless unless appraised and enforced. Regarding promises, the Prophet (pbuh) considered the words coming out from the mouth as holy and the words that fell on ears as respectable. Decency and manliness were his qualities and he never broke his promise. Islamic history is full of cases where the Prophet (pbuh) fulfilled his promise even in a very difficult situation. Allah considers fulfilling of promises as one of the attributes of Prophethood, "And make mention in the Scripture of Ishmael. Lo! he was a keeper of his promise, and he was a messenger (of Allah), a Prophet. He enjoined upon his people worship and almsgiving, and was acceptable in sight of his Lord"(Q: 19: 54-55). Nowadays, respect for and sanctity of promises especially the social promises are at stake. Social promises are tied with the community, tribes and national interest. It is a common trend to break the promise and declare it as in conflict with the community, tribes or national interest. As an example: Italy was allied to Germany in the First World War. When it suspected that its interest was with the other side, Italy joined with France and Britain. In the Second World War, when Germany thought that it would be more appropriate to attack France through Belgium, they broke all their promises to Belgium. The same is the case with Norway, Denmark and Holland. NATO and CENTO promises to member countries are other examples. Islam considers promises as sacred and discourages breaking them. If this principle of Islam becomes part of international relations, this world can be a paradise for mankind.

\section{ISLAM AND NEUTRALITY}

The Qur'an says, “And if two parties of believers fall to fighting, then make peace between them. And if one party of them doeth wrong to the other, fight ye that which doeth wrong till it return unto the ordinance of Allah; then, if it return, make peace between them justly, and act equitably. Lo! Allah loveth the equitable" (Q: 49: 9). The Prophet (SAW) said: "Help your brother irrespective of whether oppressor or being oppressed". He was asked, how an oppressor could be helped; he replied, hold his hand from oppression." (Sahih Bukhari, Volume 3, Hadith 624). The Muslim Ummah should have been supreme over Muslim groups or nations. The essential conditions of course are 
that there should be perfect fairness, justice, and respect for the highest principles. The Muslim Ummah as well as UNO fails, because these essentials are absent. Islam discourages neutrality. Abu Bakr Siddique (RAA) says, 'O people I heard Allah's Messenger (SAW) as saying, "Verily when the people see the evil but make no effort to change it (to good), Allah may inflict upon all of them His punishment" (Ibn Majah). This discouragement of being neutral is a principle to put a halt to disturbance and mutual quarrels among Muslims but it can serve as a basic principle for relations between nations. The Qur'an further says, "O ye who believe! Profane not Allah's monuments nor the Sacred Month nor the offerings nor the garlands, nor those repairing to the Sacred House, seeking the grace and pleasure of Allah. But when ye have left the sacred territory, then go hunting (if ye will). And let not your hatred of a folk who (once) stopped your going to the Inviolable Place of Worship seduce you to transgress; but help ye one another unto righteousness and pious duty. Help not one another unto sin and transgression, but keep your duty to Allah. Lo! Allah is severe in punishment." (Q: 5: 2). Similarly, the Qur'an (Q: 7: 163) highlights the character of Israel. They were prohibited from fishing on Saturday. This resulted in three groups among them, the first insisted on fishing, the second, protested and tried to halt, and the third remained undecided. When punishment came, two groups suffered, including the neutral one, but not the one, who protested and tried to stop others. This clearly reflects that neutrality is meaningless in Islam. It is advisable to be with the righteous.

\section{UNITY AND SOLIDARITY}

Unity is strength. All philosophers, from Plato to Ibn Khaldoon, commented that the national unity and solidarity (with justice) are the pivotal factors for the rise or fall of nations. Mutual unity linked each sect of the society just as each part of the human body is linked. For national up lift, it is a must that the whole nation should think and act as a single individual. Mutual recrimination, disturbance and disunity scattered the abilities and the strength. According to these philosophers, there could be many bases for national unity and solidarity, such as, race, tribe, language, color, region, objective, future dream, and a common enemy. More common things enjoin a better environment for unity. Religion and the same purpose of life can be additional bases for unity but Islam discards all other bases except the same religion. The Muslim Ummah can achieve a respectable future, if it follows just a single point in the Sunnah of the Prophet (pbuh). That single and crucial point is that the Prophet (pbuh) left his tribe in Mecca and assembled his companions in Madina. There in Madina, he assumed the managing of the religiopolitical affairs of city. Here he could affect social reforms (such as imposing Zakat for the betterment of the depressed classes of the society, to rescue the poor from the chronic debt, to improve the defense of the new-born city-state, allotting shares in the inheritance to women, regulating marriage and divorce, prohibiting usury and so forth) along with the promulgation of religio-moral and spiritual teachings of the Qur'an (such as the exclusive worship of Allah alone, a firm faith in eschatology, that is, the day of judgment and the life hereafter), then fight back with them till the victory of Mecca. Consequently, his own tribe became believers and followers. In the battle of Badr, he begged Allah (swt) for His blessing, help and victory of his companions against his own tribe. Therein, his uncle, a son of Abu Bakr Siddique (ra), a brother of Ali (ra), the uncle of Umar Farooq (RAA) and relatives of the companions were on one side representing his tribe and the Prophet (pbuh) and his devoted companions were fighting against them. Between the battle of Badr and the victory of Mecca, color, race, language, clan, region, and all factors, which constitute a tribe, were in Mecca while his companions were residing in Madina. May the Muslim 
world understand this single crucial point and put aside the mutual differences, concentrate on unity and solidarity! This will assure a respectable future for them; otherwise they will be mercilessly crushed all over the world and will be buried in the dust of history.

\section{ESTABLISHMENT OF UNITY AND SOLIDARITY}

Establishment of justice, national unity and solidarity, and an effective defensive and strategic system are pivotal ingredients to assure future security. Different sects of a nation can only be united if treated fairly (with justice) and given a chance to participate actively in the affairs of state. This will obviously strengthen national unity and provide inspiration and motivation to sacrifice property and even life, if needed, for national defense. End to justice is also an end to unity and solidarity. Despotism and oppression are the root cause for national destruction. Deprivation results in decline of sacrifices. Hence, discrimination in state affairs divides a nation and gives rise to the feeling of hatred, resulting in national disunity. Consequently, national resources will be utilized for destruction and disturbance rather than national construction, causing internal strife, which finally invites external aggression and ultimately foreign occupation. Muslim Ummah is really lacking to establish justice, which is the basis of morality and hence good deeds. The Qur'an says, "O ye who believe! Be ye staunch in justice, witnesses for Allah, even though it be against yourselves or (your) parents or (your) kindred --- (Q: 4: 135). According to the Qur'an, the objective of Islam and hence the Muslim Ummah is to exhort to do good and forbid evil and continue this practice (jihad) till there is an end to oppression and evil. Abu Bakr Siddique (ra) said: 'O people I heard Allah's Messenger (pbuh) as saying', "Verily when the people see the evil but make no effort to change it (to good), Allah may inflict upon all of them His punishment" (Ibn Majah). Establishment of a just socio-moral order must be the top priority. Islam can only be established in the world if we Muslims establish and really practice Islam in our home and at the national level. To ensure unity and solidarity, the Muslim world should immediately bring social justice in the daily life practices. Mutual unity is a source of blessing to fight against evil.

\section{KNOWLEDGE AND LITERACY}

The first revelation called upon the Prophet (pbuh) and humanity to pursue education and acquire knowledge in accordance with the Divine guidance of Allah; "Read and understand in the Name of the Lord and Cherisher" (Q: 96: 1). The Qur'an says, "Allah will raise up to honorable ranks (and degrees) those of you who believe and who have been granted knowledge (Q: 58: 11). Adam (ra) was raised to the highest rank among

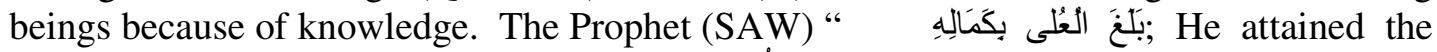
height of eminence by his perfection; كَثَفَ الأُجى بجَمَالِلِّ ; He dispelled the darkness (of the

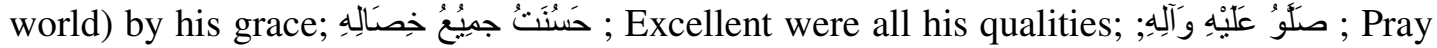
for blessings on him and his descendants" (Shaikh Sa'di Sheeraazi (ra)). He is asked in the Qur'an to pray for an increase in knowledge (ربّ زدني علما). The Prophet (pbuh) also said: "Acquire knowledge from cradle to grave" (Muttafaqun Alaih). He further stated that the acquisition of knowledge is a duty imposed on every Muslim (Ibn Maajeh Vol. 1, section 17, Hadith 224). It is inspiring to recall that the very first word that was revealed to him is Iqra (read). Human beings have many qualities which are latent or which they may wish to suppress or conceal to their own detriment. The Prophet (pbuh) also said: "Wisdom is the lost property of the Muslim; he recovers it wherever he finds it" "(Tirmizi). This is inspiring and indicates that there is no monopoly in matters of 
knowledge. Among children of Adam (ra), those who excel in knowledge and wisdom, are the world leaders and hold the office of Imam. Knowledge and wisdom protect your ideological boundaries from evil. The Muslim Ummah, unfortunately, failed to excel in knowledge and wisdom. Acquiring knowledge and understanding it (research) is left to the others, resulting a degradation in science and technology as well as in trade and business. The Prophet (pbuh) said that knowledge is a foundation of Islam. Regarding this let us look at the Prophet's (pbuh) concern, attitude and priority. To educate Muslim children up to reading level, he even asked the prisoners of Badr, who were the nonbelievers of Mecca, and considered this as their compensation. This reflects his concern about education and treatment of prisoners of war at a time when Muslims were fighting for very survival. There is a difference in acquiring knowledge, understanding knowledge, and education targeting literacy. To increase the rate of literacy among Muslims, the Prophet (pbuh) utilized the services of even the non-believers of Mecca, i.e., prisoners of Badr. Knowledge must be of truth and reality or of what the Qur'an calls Haqq. Unfortunately, Muslim Ummah has confused knowledge with literacy. The dilemma is that we are utilizing our resources to increase the rate of literacy rather than acquiring knowledge, even then we fail in it. May Allah (SWT) bless us to fulfill our duties of acquiring and understanding knowledge, bring back our virtues and qualities, that is., competence, energy, initiative, seriousness, creativity, and wisdom, and enabling us for the world leadership (with justice) and to hold the office of Imam.

\section{MUTUAL RELATIONSHIP}

A man who harasses his neighbor and makes him suffer any kind of damage is called cruel and stone-hearted by the religion. Regarding this, the Prophet (SAW) said: "By God, he cannot be a Momin; by God, he cannot be a Momin; by God, he cannot be a Momin (Bukhari). He was asked; "who"? He answered; "He from whose misdeeds his neighbor is not safe" (Bukhari). In the present day scenario, arms race among the countries is the root cause for mutual tension among the regional powers. If we just follow the above Hadith of the Prophet (SAW) as a basic principle for international relations, this world can be turned into a cradle of peace. The overriding objective of Islam is to establish a just moral order and hence the peace. Islam wishes an end to oppression resulting in a peaceful environment, wherein humankind can utilize their abilities and perform significantly for their betterment. The Qur'an says, "Then, even after that, your hearts were hardened and became as rocks, or worse than rocks, for hardness. For indeed there are rocks from out which rivers gush, and indeed there are rocks which split as under so that water floweth from them. And indeed there are rocks which fall down for the fear of Allah (swt). Allah (swt) is not unaware of what ye do" (Q: 2: 74). Hence, based on character and deeds, Qur'an has divided humankind into four groups and compared them with rocks. The first kinds of rocks are the sources of rivers. A wide range of regions benefit from the water, nursing crops and gardens. Humankind, animals and plants all benefit. (People belonging to the party of Allah (swt) live a similar life). The second kinds of rocks are the source of springs and are beneficial to the surroundings. The third kinds of rocks are those, which do tremble with the fear of Allah (swt) but yet have to be melted to become beneficial. The last kinds of the rocks are neither the source of rivers or springs nor have fear of Allah (swt). These are just solid unkind stones, lying in rivers just to stop and divert the flow. Present days Muslims are just like this fourth type, neither beneficial to themselves nor to others but instead, are hurdles in the path of goodness and virtue. 
IIUM Engineering Journal, Vol. 12, No. 5, 2011: Special Issue on Science and Ethics in Engineering

Azram

\section{MILITARY AND DEFENSIVE CAPABILITIES}

While knowledge protects ideological boundaries, jihad protect the geographical and territorial frontiers, safeguards our lives, honor and dignity, besides the preservation of resources. Military and defensive capabilities are to protect natural, mineral and financial resources as well as national sovereignty. The Qur'an says that the standard of military and strategic preparations should be as if we are in an actual war. This will not only halt and discourage your enemies and the enemies of Allah (SWT) but they will not dare to attack a Muslim state. Abu Bakr Siddique (ra) observes in his inaugural address [4] that if a community begins to tolerate moral indecency and allows the spirit of jihad to cool down, it surrenders its right to exist on the face of the earth and qualifies instead for a safe burial. Even today, Muslim Ummah might be aspiring for jihad but in the present scenario, military and strategic strength depends on advanced technology, which unfortunately, we left to the others. Since Muslims have allowed their spirit of jihad to cool and have adopted an apologetic attitude, they have placed themselves at the mercy of their enemies. Innocent men, women and children are being killed in Palestine, Iraq, Afghanistan, Pakistan, Kashmir, Chechnya, Bosnia, Kosovo, and in so many other trouble spots, while we do not hear even ordinary murmurings in the Muslim world. We are just helpless spectators of the brutal massacre of Muslims. Among fifty seven Muslim states, none is in a position to defend itself. We have to wake up. Defense will only be possible if the Muslim Ummah excel in science and technology especially computer and nuclear technology, and do not compromise on any issue regarding this. It is interesting to note that in early Islamic days, Iran and Rome were considered to be world powers. The newborn Islamic State of Madina was lagging behind in military power, economy, education, science and technology, like us. Their objective was clearly defined and pursued; hence, they succeeded in all fields. Muslim Ummah even today, if it concentrates on the moral and educational values, can achieve its target. Allah changes history through ill-equipped but truth-loving people. The well known poet, thinker, and philosopher Allama Iqbal rightly said: "Momin soldier, fight (jihad) even without sword"[9].

\section{ALLAH-FEARING LEADERSHIP}

All expectations and dreams can become true if our leadership fear the Supreme Power rather than the superpower, that is., fear Allah (swt) rather than non-believers. Muslim Ummah needs leadership, who fear Allah (swt), are dedicated to serve humanity, consider the resources of the Ummah as amanah (trust), and utilize these resources for the betterment and welfare of humanity, interested in lighting the lamp rather than blowing it off. They should strive for providing the basic necessities to the community rather than making their lives miserable. A famous event in the life of Umar Farooq (ra) is stated below in the hope that our leadership may get a lesson from it and consider this as a torch for their attitude. Umar Farooq (ra) [1] used to live a simple life and insisted also to his appointed governors to live simple lives, keep no guard at their doors and be accessible to people at all time. Once, he was on a routine night watch going about the streets to see whether anyone needed help. He heard cries from a house. He ignored the cries, thinking that it may be unnecessary to interfere in family privacy. Next night, he observed a similar situation from the same house. Upon inquiry, the lady of the house informed him that the children were hungry. He asked the lady about the previous night. She replied that there was nothing to eat at home. Yesterday I putted an empty pot on fire, just for their satisfaction and hope but today even this trick failed. Umar Farooq (ra), without 
IIUM Engineering Journal, Vol. 12, No. 5, 2011: Special Issue on Science and Ethics in Engineering

Azram

introducing himself, asked the lady about not asking the Caliph for assistance. She replied; It should have been the moral and social responsibilities of the Caliph to be watchful and aware about the needs of the poor; instead, we poor go to his door for begging. Umar Farooq (ra) argued how the Caliph could know the needs of the poor and hungry among so many people. She replied; If the Caliph is lacking these qualities, he must leave his office to give the chance to a better replacement. After hearing this, Umar Farooq (ra) trembled with fear of Allah (SWT) and then rushed to the public treasury and filled a bag to its maximum with food stuff. While he intended to comeback, the guard offered his services to carry to the destination. He replied; This is my own burden, let me lift this burden by myself. He offered the food to the lady. Upon that, the lady responded and prayed for him by saying, "O brother, may Allah (swt) bless you and bless you to be our Caliph rather than Umar Farooq (ra)". At that stage, Umar Farooq (ra) introduced himself and requested the lady to Pray for forgiveness for his negligence. Only Allahfearing leaders can assure, excel, and take the Ummah out of the darkness of negligence and illiteracy. They can lead us to gain knowledge, wisdom, thoughtfulness, attitude of collective decision, justice and consequently, unity and solidarity. This will help us to fulfill our military and strategic needs so that oppression from enemies can be avoided. An Allah-fearing leadership can only bring the nations and hence the Ummah to a level to be called Vicegerents. Spreading goods, halting and stopping oppression can be considered as a moral obligation by only an Allah-fearing leadership.

\section{CONCLUSION}

The Qur'an says, "He it is who hath sent His messenger with the guidance and the religion of truth, that He may make conqueror of all religion, however much idolaters may be averse" [Q: 61: 9]. The Prophet (pbuh) and Caliphs had faced more complex and difficult challenges but within decades, Islam prevailed and for centuries the power of Islam pre-dominated. Presently, Muslims are in the doldrums. Non-believers have predicted the destiny, "If any religion has a chance of conquering England, nay Europe within the next hundred years, that religion is Islam" [7], similarly, "Africa is a fair field for all religions, but the religion which the Africans will accept, is a religion which best suits their needs; And that religion, every-one who has a right to speak on the subject says, is Islam". [8].

The promise of Allah (swt) is true (wish this news does not lull us to sleep), the destiny is there, only dedication, motivation, strategic planning and exertion on our part, as an individual, as a community, and as an Ummah, is the call of today. May Allah bless us to serve for His Cause (Ameen).

\section{REFERENCES}

[1] Atiah, Muhammad Sabri. 1991. Waqfah ma'a Omar bin al-Khatab, Dar al-Sharqih, Cairo.

[2] Ibn Kathir, Ibi al- Fida'a. 1985. Al-Bidayah wa-al-Nihayah, Vol. 4, Dar al-Kutub al-Ilmih, Bayrut

[3] Ibn Kathir, Ibi al- Fida'a. 1985. Al-Bidayah wa-al-Nihayah, Vol. 5, Dar al-Kutub al-Ilmih, Bayrut

[4] Mohammad, Ibn Ahmad. 1997. Al-Khalifah al-Rashidah, Mu'assasat al-Ma'arif, Bayrut.

[5] Ibn Taymiyah, Ahmad ibn Abd al-Halim. 1976. Al-amr bi-al-ma'ruf wa-al-nahyi'an almunkar, Dar-al-Kitab al-Jadid, Bayrut.

[6] http://web.youngmuslims.ca/online_library/books/let_us_be_muslims/ch5top19.html

[7] Sir George Bernard Shaw. 'The Genuine Islam,' Vol. 1, No. 8, 1936.

[8] H. G. Wells. The Shape of Things to Come, The Macmillan Co (NY), 1933 
IIUM Engineering Journal, Vol. 12, No. 5, 2011: Special Issue on Science and Ethics in Engineering Azram

[9] http://www.memri.org/report/en/print3971.htm\#_ednref1 